\title{
Impact of Nitrogen Fertilizer Applications on Surface Water Nitrate Levels within a Kenyan Tea Plantation
}

\author{
J. K. Maghanga, ${ }^{1}$ J. L. Kituyi, ${ }^{2}$ P. O. Kisinyo, ${ }^{3}$ and W. K. Ng'etich ${ }^{3}$ \\ ${ }^{1}$ Department of Chemistry and Biochemistry, Pwani University College, P.O. Box 195, Kilifi 80108, Kenya \\ ${ }^{2}$ Department of Chemistry and Biochemistry, Chepkoilel University College, P.O. Box 1125, Eldoret 30100, Kenya \\ ${ }^{3}$ Department of Soil Science, Chepkoilel University College, P.O. Box 1125, Eldoret 30100, Kenya
}

Correspondence should be addressed to J. K. Maghanga; justinmaghanga@yahoo.com

Received 22 June 2012; Revised 13 November 2012; Accepted 20 November 2012

Academic Editor: Isabel Seiquer

Copyright (c) 2013 J. K. Maghanga et al. This is an open access article distributed under the Creative Commons Attribution License, which permits unrestricted use, distribution, and reproduction in any medium, provided the original work is properly cited.

Tea production in the Kenyan Rift Valley uses high rates of nitrogenous fertilizer. Nitrates can be discharged to water bodies through leaching and surface run-off. Nitrate levels above $10 \mathrm{mg} / \mathrm{L} \mathrm{NO}_{3}{ }^{-}-\mathrm{N}$ cause methemoglobinemia which is fatal. A study to monitor changes in surface water nitrate levels was carried out in ten rivers within a Kenyan tea plantation for three years. Water samples were obtained before and after fertilizer application in 2004, 2005, and 2006. Nitrate-nitrogen $\left(\mathrm{NO}_{3}{ }^{-}-\mathrm{N}\right)$ was determined colorimetrically by the cadmium reduction method using HACH-DR 2400 dataloging spectrophotometer. For the three years, the highest nitrate-nitrogen levels were in river Temochewa in 2005 during the first fertilizer applications ( $4.9 \mathrm{mg} / \mathrm{L}$ to $8.2 \mathrm{mg} / \mathrm{L}$ ). There was no established trend between surface water nitrate levels and the time of fertilizer applications; however, fertilizer application contributed to an increase in nitrate levels. The initial nitrate-nitrogen levels in most of the rivers were high, indicating that contamination could have been upstream; hence, further research is required to establish this. Nitrogen-nitrogen levels in the three years were below the maximum contaminant level of $10 \mathrm{mg} / \mathrm{L} \mathrm{NO}_{3}{ }^{-}-\mathrm{N}$; however, the rivers should be monitored frequently.

\section{Introduction}

Tea production is the main agricultural activity practiced in the Kenyan highlands and Rift valley. The optimum production of a mature tea field is $3,500 \mathrm{~kg}$ made tea per hectare per year [1]; hence, to sustain the yields, soil nutrients are replenished by the use of inorganic compound fertilizers. In Nandi Hills tea plantations, about 5,000 hectares of land are under mature tea and fertilizer is applied at a rate of $140 \mathrm{Kg} \mathrm{N} / \mathrm{ha} /$ year. The most commonly used fertilizer is $25: 5: 5$ and $22: 6: 12$ split twice; hence, $2,800-3,181$ tons of fertilizer are used respectively. The nitrogen component is in the form of $\mathrm{NO}_{3}{ }^{-}$and $\mathrm{NH}_{4}{ }^{+}$. Nitrates are very mobile and loosely bound in the soil hence easily leached. In Nandi South district, fertilizer application is carried out during rainy seasons in May and October; hence, surface runoff and leachate get into rivers passing through the tea plantations which could cause river eutrophication and nitrate pollution.

The determination of nitrate levels in surface waters is an integral part of basic water quality assessment because its concentration is generally an indicator of the nutrient status and the degree of organic pollution of the water body. Regular monitoring of nitrate for in drinking water is recommended because of the potential health risks associated with its elevated levels, especially for infants below six months old and animals [2].The major source of accumulated nitrates in drinking water, surface water, and the environment is nonpoint source from excessive use of nitrate based fertilizers or from inadequately treated or untreated sewage $[2,3]$. Other sources of nitrate include wastes produced by certain industrial processes such as paper and munitions manufacturing, point sources, runoff from human and animal wastes septic/solid disposal, and landfills [4-6].

Nitrates are released into the soil and water through a breakdown of naturally occurring organic nitrogen compounds through mineralization, hydrolysis, and bacterialactivated reactions $[7,8]$. Urea like other forms of organic nitrogen in soil and natural waters is converted to ammonia under anaerobic microbial processes [8]. Ammonia is also converted to nitrate and nitrite which are soluble in water 


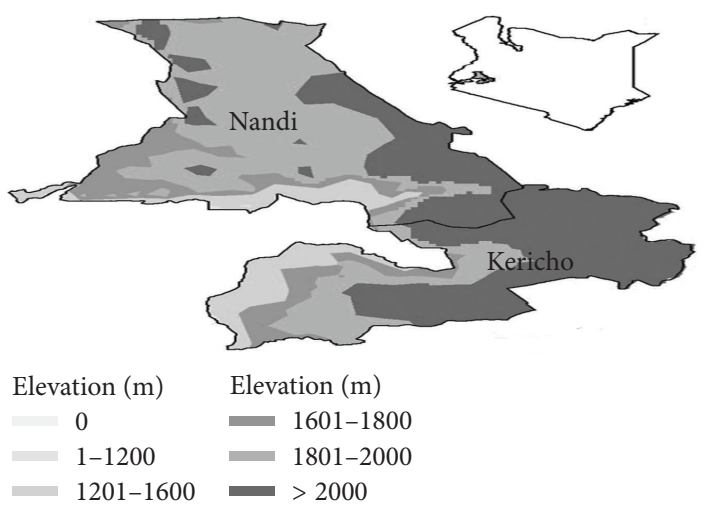

FIGURE 1: Map of Nandi South district.

both of which do not bind to soil and have high migration potential through soil. Consequently, nitrates are washed easily into surface waters by rain or leached through soil into ground water. Plant cover, land use, fertilizer pattern, fertilizer usage, soil type, rainfall pattern, irrigation, climatic conditions, and depth of ground water below land surface are the main factors that control the leaching of nitrates as well as nitrites [9].

Consumption of drinking water contaminated with high levels of nitrates by infants below six months old and certain young animals causes "oxygen debt" in the blood, a fatal condition known as methemoglobinemia or blue baby syndrome [10-13]. The nitrite from ingested nitrate can react with amines and amides in human stomach to produce a highly carcinogenic N-nitroso compounds in the body. Cattle, sheep, baby pigs, chicks, and horses are also susceptible to nitrate poisoning [14]. The oxidation of nitrite to nitrate by dissolved oxygen in water leads to depletion of the oxygen level in water [15]. The US Environmental Protection Agency (USEPA) and National Environmental Authority in Kenya (NEMA) fixed a MCL of $10 \mathrm{mg} / \mathrm{L}, \mathrm{NO}_{3}-\mathrm{N}[16,17]$.

\section{Methodology}

2.1. Sampling and Pretreatment. Surface water samples were collected from ten major rivers passing through Eastern Produce Kenya Ltd tea plantations in Nandi South district (Figure 1). The rivers are Mogobich, Temochewa, Kapsumbeiwa, Kibabet 1, Kamasai, Kibabet 2, Mokong, Kirondio, Kimutein, and Kamngorion. Samples were collected before and after fertilizer applications. Samples were collected in cleaned 2.0 L, brown borosilicate bottles, filled and sealed with Teflon lined caps. The bottles were transferred to the laboratory in a big plastic cooler box and subsequently stored in a refrigerator at $4^{\circ} \mathrm{C}$ immediately on reaching the laboratory. This helps to retard biological degradation as well as the rates of possible physical and chemical reactions. Samples were filtered and analyzed within $48 \mathrm{~h}$ of refrigeration [18]. From each sampling point three samples were collected over a period of four months in 2004, 2005, and 2006 at an interval of four weeks.
2.2. Determination of Nitrates. The analysis of nitrates is carried out using the advanced water quality laboratory series HACH-DR 2400 datalogging spectrophotometer. This is a microprocessor-controlled LED-sourced filter photometer with in-built programs for measurements of various parameters in water including $\mathrm{NO}_{3}-\mathrm{N}$ at programmed wavelengths and reaction times. The method for nitrate analysis utilizes the quantitative reduction of nitrate in the sample to nitrite by cadmium and subsequently production of the ambercoloured product. The product is done through the reaction of the nitrite with sulphuric acid and the coupling of the formed diazonium salt with gentisic acid that produces colour with intensity proportional to the original $\mathrm{NO}_{3}-\mathrm{N}$ in the sample. Interference by nitrite is compensated by addition of bromine water followed by phenol [19].

A $10 \mathrm{~mL}$ cell was filled with the sample and bromine water added dropwise until the developed yellow colour stabilized. This was followed by a drop of phenol solution to produce a colourless solution. A Nitra Ver 5 nitrate reagent powder pillow was added then shaken for 1 minute and allowed to stand for five minutes to complete the reaction. A blank was made by filling a $10 \mathrm{~mL}$ cell, placed in the cell compartment, and used to zero the instrument. The prepared sample was then placed in the cell compartment and the concentration of the nitrate read in $\mathrm{mg} / \mathrm{L} \mathrm{NO}_{3}-\mathrm{N}$ [19].

\section{Results and Discussion}

The results of nitrate levels in 2004 are presented in Table 1. There was a general increase in nitrate levels after the first application of fertilizer. However, the highest nitrates recorded were $2.6 \mathrm{mg} / \mathrm{L}$ and $3.0 \mathrm{mg} / \mathrm{L}$ in river Kirondio before the first and second applications of fertilizer, respectively. These values indicate possibility of surface water contamination as the natural nitrate-nitrogen levels in surface water are generally less than $1 \mathrm{mg} / \mathrm{L}$ [20]. After the first and the second fertilizer applications, rivers with more than $1 \mathrm{mg} / \mathrm{L}$ were $60 \%$ and $20 \%$, respectively. The levels reduced significantly after the second application of fertilizer suggesting no possible point source pollution. Results indicate that there was no relationship between fertilizer application seasons and 
TABLE 1: Nitrate-nitrogen levels in 2004.

\begin{tabular}{lcccc}
\hline \multirow{2}{*}{ River } & \multicolumn{2}{c}{ First application } & \multicolumn{2}{c}{ Second application } \\
& Before & After & Before & After \\
\hline Mogobich & 0.5 & 0.8 & 1.0 & 0.1 \\
Temochewa & 1.3 & 1.3 & 1.1 & 0.3 \\
Kapsumbeiwa & 1.1 & 1.4 & 1.0 & 0.2 \\
Kibabet 1 & 1.4 & 1.0 & 1.0 & 0.9 \\
Kamasai & 0.3 & 0.3 & 0.4 & 0.0 \\
Kibabet 2 & 0.5 & 0.3 & 0.4 & 0.1 \\
Mokong & 1.4 & 1.6 & 1.3 & 0.6 \\
Kirondio & 2.6 & 2.4 & 3.0 & 1.6 \\
Kimutein & 2.4 & 1.9 & 2.2 & 1.1 \\
Kamngoriom & 2.0 & 1.8 & 2.0 & 0.9 \\
\hline Means & 1.4 & 1.3 & 1.3 & 0.6 \\
\hline
\end{tabular}

TABLE 2: Nitrate-nitrogen levels in 2005.

\begin{tabular}{lcccc}
\hline \multirow{2}{*}{ River } & \multicolumn{2}{c}{ First application } & \multicolumn{2}{c}{ Second application } \\
& Before & After & Before & After \\
\hline Mogobich & 0.3 & 0.6 & 0.5 & 1.0 \\
Temochewa & 4.9 & 8.2 & 5.6 & 7.1 \\
Kapsumbeiwa & 0.3 & 0.7 & 0.7 & 1.6 \\
Kibabet 1 & 0.4 & 0.9 & 1.4 & 2.0 \\
Kamasai & 0.0 & 0.3 & 0.0 & 0.2 \\
Kibabet 2 & 0.0 & 0.3 & 0.0 & 0.7 \\
Mokong & 0.5 & 0.0 & 0.0 & 1.5 \\
Kirondio & 1.0 & 0.0 & 0.0 & 2.7 \\
Kimutein & 0.1 & 0.0 & 1.8 & 2.4 \\
Kamngoriom & 0.6 & 0.0 & 1.5 & 2.2 \\
\hline Means & 0.8 & 1.1 & 1.2 & 2.1 \\
\hline
\end{tabular}

surface water nitrate levels and contamination could have occurred before the water reached the tea plantations.

Table 2 shows the levels of nitrates in 2005. There was a general increase in nitrate levels after the first and second fertilizer applications. Temochewa River had an increase of $67.3 \%$ from 4.9 to $8.2 \mathrm{mg} / \mathrm{L}$ in the first application and $0.27 \%$ in the second application. This suggests surface runoff from the soil to the river after application; however, the levels were below the MCL. However, $90 \%$ of the rivers had initial nitrate levels below $1 \mathrm{mg} / \mathrm{L}$ implying the inherent nitrate characteristics of the water.

Nitrate levels in 2006 are shown in Table 3. There was a general increase in nitrate levels from $1.8 \mathrm{mg} / \mathrm{L}$ to $2.3 \mathrm{mg} / \mathrm{L}$. The highest nitrate levels were recorded in river Kirondio $(4.8 \mathrm{mg} / \mathrm{L})$ before the first application of fertilizer which reduced to $4.6 \mathrm{mg} / \mathrm{L}$ after fertilizer application. All the rivers recorded an increase in nitrate levels after the first fertilizer application which indicate possible surface runoff. However, in river Kirondio a reduction of $0.2 \mathrm{mg} / \mathrm{L}$ was observed which could be a fluctuation in the inherent nitrate levels in the river. It was observed that about $70 \%$ of the rivers had levels above $1 \mathrm{mg} / \mathrm{L}$ even before fertilizer applications and this could be contamination from upstream. In the second fertilizer application, there was a mean decrease in nitrates in
TABLE 3: Nitrate-nitrogen levels in 2006.

\begin{tabular}{lcccc}
\hline \multirow{2}{*}{ River } & \multicolumn{2}{c}{ First application } & \multicolumn{2}{c}{ Second application } \\
& Before & After & Before & After \\
\hline Mogobich & 0.6 & 1.3 & 5.7 & 2.8 \\
Temochewa & 3.4 & 3.0 & 2.2 & 1.3 \\
Kapsumbeiwa & 1.1 & 1.3 & 2.3 & 1.7 \\
Kibabet 1 & 1.1 & 2.3 & 1.6 & 1.6 \\
Kamasai & 0.6 & 0.9 & 0.2 & 0.1 \\
Kibabet 2 & 0.2 & 0.8 & 0.4 & 0.4 \\
Mokong & 2.1 & 3.6 & 1.6 & 1.3 \\
Kirondio & 4.8 & 4.6 & 2.9 & 2.5 \\
Kimutein & 2.6 & 3.4 & 2.2 & 2.1 \\
Kamngoriom & 1.9 & 2.1 & 1.8 & 1.8 \\
\hline Means & 1.8 & 2.3 & 2.1 & 1.6 \\
\hline
\end{tabular}

TABLE 4: Recommended MCL for nitrates in drinking water.

\begin{tabular}{lcc}
\hline Organization & \multicolumn{2}{c}{ Nitrate $(\mathrm{mg} / \mathrm{L})$} \\
\hline USEPA & $\mathrm{NO}_{3}{ }^{-} \mathrm{N}$ & $\mathrm{NO}_{3}{ }^{-}$ \\
WHO & 10 & 45 \\
KEBS & 10 & 50 \\
Canada & 10 & 45 \\
\hline
\end{tabular}

Source [19].

all the ten rivers from 2.1 to $1.6 \mathrm{mg} / \mathrm{L}$ after the application. The results indicate that there was no relationship between fertilizer applications and surface water nitrate levels.

In the three years, the highest nitrate-nitrogen levels of $8.2 \mathrm{mg} / \mathrm{L}$ were found in river Temochewa in 2005 which indicated surface run-off contamination as a result of fertilizer application. However, the levels were below the MCL (KEBS) as shown in Table 4.

The total rainfall values for the four months (April, May, October, and November) are shown in Figure 2. Rainfall had a range of $315-608 \mathrm{~mm}$ in 2004, 321-688 $\mathrm{mm}$ in 2005, and 221-676 in 2006. In general there was no direct relationship between the amount of rainfall and surface nitrate levels apart from Temochewa River (2005) that had the highest rainfall level that corresponded to the highest nitrate levels. The soils being mostly nitisols are well drained with little runoff to the rivers.

\section{Conclusion}

In this paper, the effect of fertilizer application on surface water nitrate levels was investigated. There was an effect of runoff observed in 2006 after the first application as the nitrate levels increased. However, the levels were below the MCL value with a mean $2.3 \mathrm{mg} / \mathrm{L}$. In 2004 and 2005, the results do not indicate any relationship between the time of fertilizer application and surface water nitrate-nitrogen levels. In the three years, nitrate levels in the ten rivers before and after fertilizer application were below the MCL of $10 \mathrm{mg} / \mathrm{L} \mathrm{NO}_{3}{ }^{-} \mathrm{N}$. River Temochewa had the highest value 


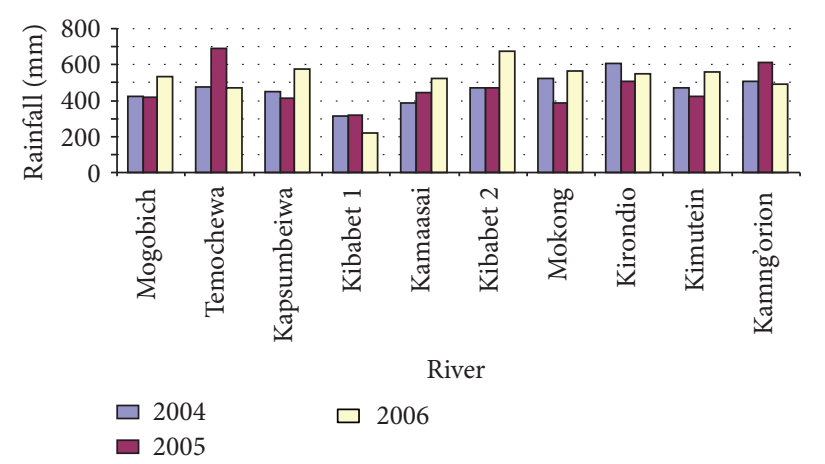

FIGURE 2: Four-month total rainfall in 2004, 2005, and 2006. Source [1].

of nitrate-nitrogen in the three years $(8.2 \mathrm{mg} / \mathrm{L})$ indicating possible contamination by surface runoff. The initial nitratenitrogen levels in 2005 were high ( 4.9 and $5.6 \mathrm{mg} / \mathrm{L}$, resp.) indicating that contamination could be upstream and the increase could be a cumulative combined effect. The soils being nitisols have good drainage characteristics which minimizes surface runoff. It is concluded that application of NPK fertilizer contributed to increase in surface water nitratenitrogen levels although not to toxic levels. It is recommended that rivers with nitrate-nitrogen levels more than $1 \mathrm{mg} / \mathrm{L}$ may be investigated upstream to determine the exact source of contamination. The effects of nitrate-nitrogen levels can be seen at the Lake Victoria basin which receives discharge of water from semitreated factory effluents and surface runoff containing nitrogenous fertilizer.

\section{Acknowledgment}

The authors acknowledge Eastern Produce Kenya Ltd. for facilitating sampling and analysis.

\section{References}

[1] EPK, Technical Annual Report, Eastern Produce Kenya, 2006.

[2] N. F. Gray, Drinking Water Quality Problems and Solutions, John Wiley and Sons, New York, NY, USA, 1994.

[3] M. J. Hill, Nitrates and Nitrites in Food and Water, Ellis Horwood, New York, NY, USA, 1991.

[4] L. J. Pucket, "Nonpoint and point sources of nitrogen in major watersheds of the United States," U.S. Geological Survey, WaterResources Investigations Report 94-4001, USGS, Reston, Va, USA, 1994.

[5] A. K. De, Environmental Chemistry, Wikley Eastern, New Delhi, India, 3rd edition, 1994.

[6] L. Pucket, "Identifying the major sources of nutrient water pollution," Journal of Environmental Science and Technology, vol. 29, no. 9, pp. 408A-414A, 1995.

[7] B. T. J. Nalan, "Nitrate behavior in ground waters of the Southeastern USA," Journal of Environmental Quality, vol. 28, pp. 1518-1527, 1999.

[8] G. K. Speriran, "Geohydrology and Geochemistry near coastal ground-water-discharge areas of the Eastern Shore, Virginia," U.S. Geological Survey Water-Supply Paper 2479, USGS, Richmond, Va, USA, 1996.
[9] L. J. Puckett and T. K. Cowdery, "Transport and fate of nitrate in a glacial outwash aquifer in relation to ground water age, land use practices, and redox processes," Journal of Environmental Quality, vol. 31, no. 3, pp. 782-796, 2002.

[10] J. De Zuane, Drinking Water Quality, Standards and Controls, Van Nostrand Reinhold, New York, NY, USA, 1990.

[11] W. S. Holden, Water Treatment and Examination (Edited for "the Society for water Treatment and Examination"), J. and A. Churchill, London, UK, 1970.

[12] B. T. Nolan, K. J. Hilt, and B. C. Ruddy, "Groundwater hydrology," Environmental Science \& Technology, vol. 36, pp. 21-38, 2002.

[13] D. K. Mueller, P. A. Hamilton, D. R. Helsel, K. J. Hilt, and B. C. Ruddy, "Nutrients in groundwater and surface water of the United States-an analysis of data through 1992," U.S. Geological Survey, Water-Resources Investigations Report 954031, USGS, Denver, Colo, USA, 1995.

[14] D. D. Jennings and R. E. Sneed, "Water quality and waste management," Publication no. AG 473-4, North Carolina Cooperative Extension Service, 1996.

[15] K. Horita, G. Wang, and M. Satake, "Spectrophotometric determination of nitrate and nitrite in soil and water samples with a diazotizable aromatic amine and coupling agent using column preconcentration an naphthalene supported with ionpair of tetradecyldimethylbenzylammonium and iodide," Analytica Chimica Acta, vol. 350, no. 3, pp. 295-303, 1997.

[16] U.S. Environmental Protection Agency Water, Consumer Facts Sheet on Nitrates and Nitrites, 2002, http://www.epa.gov/.

[17] Kenya Bureau of Standards, "Drinking water standards," Kenya Standards 049-196, 1996.

[18] D. Chapman, Water Quality Assessment. A Guide to the Use of Biota, Sediments and Water, Chapman and Hall, London, UK, 1992.

[19] HACH Company, DR-2010 Series Data Logging Spectrophotometer: Operations and Procedures Manual, Hach Company, Loveland, Colo, USA, 1992.

[20] APHA, Standard Methods for the Examination of Water and Wastewater, American Public Health Association, Washington, DC, USA, 18th edition, 1992. 

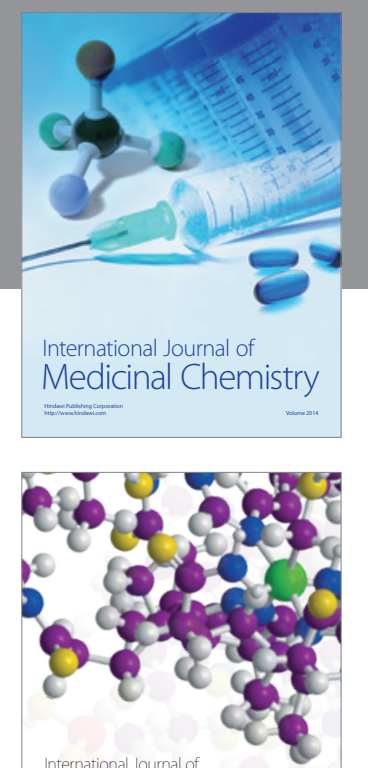

\section{Carbohydrate} Chemistry

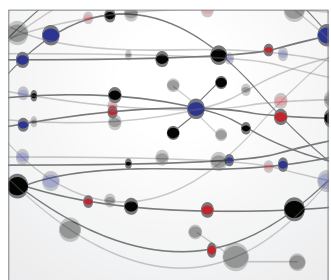

The Scientific World Journal
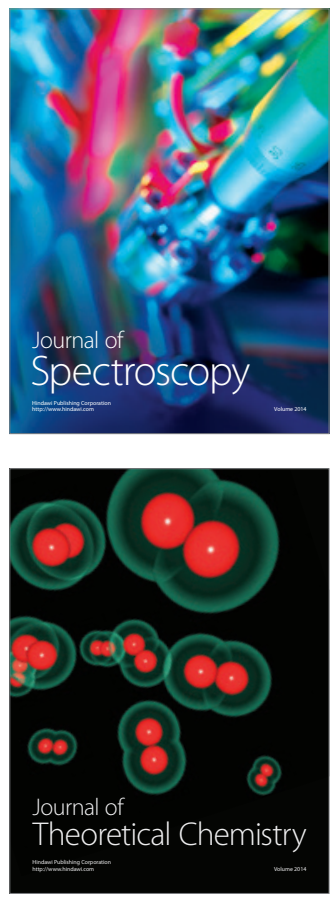
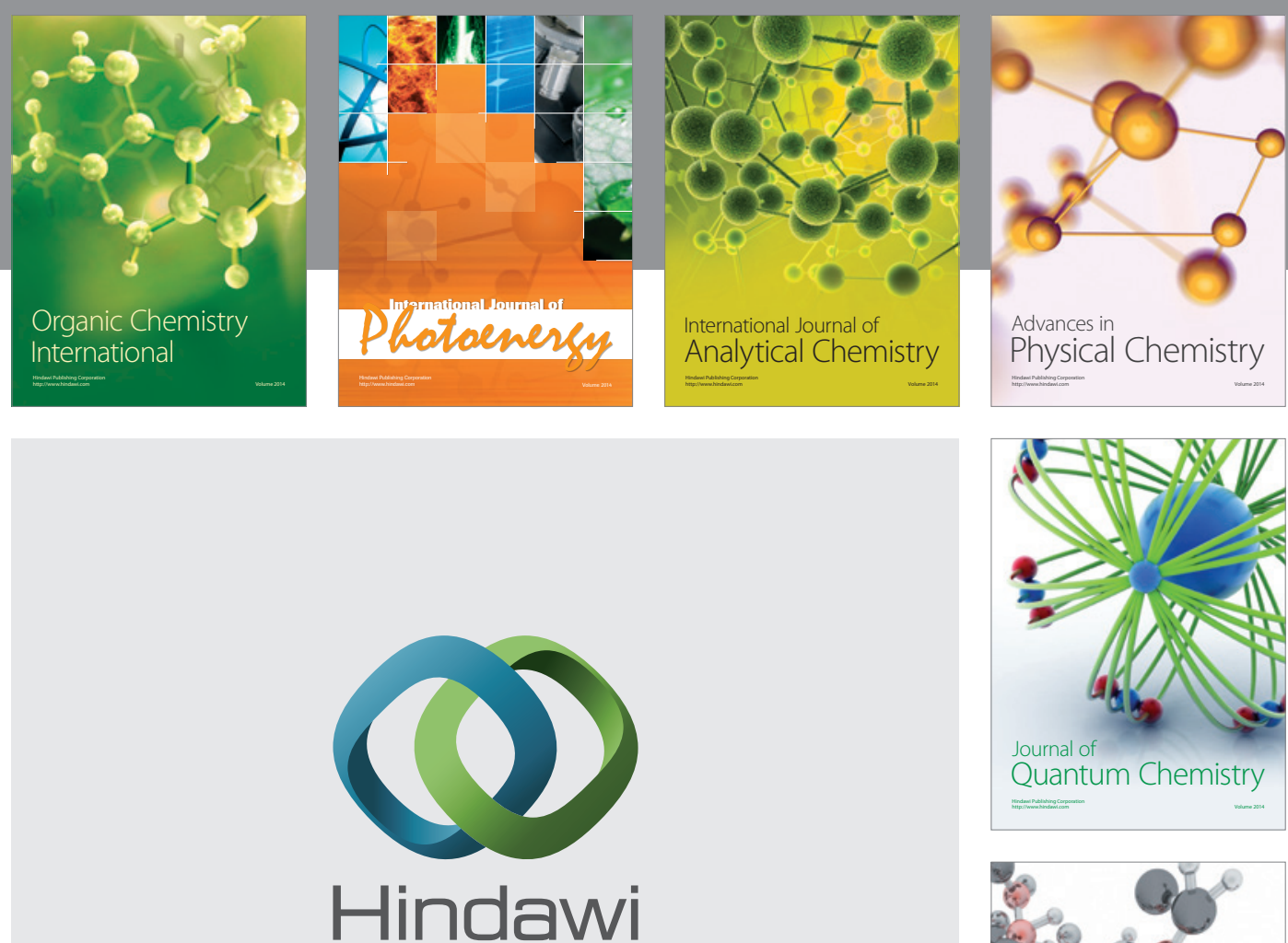

Submit your manuscripts at

http://www.hindawi.com

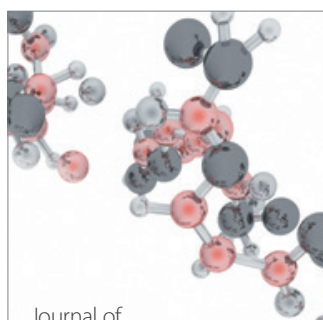

Analytical Methods

in Chemistry

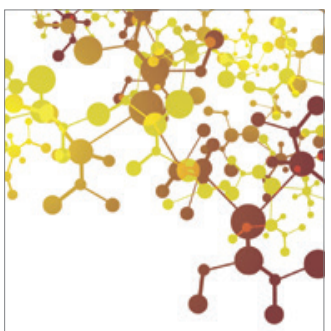

Journal of

Applied Chemistry

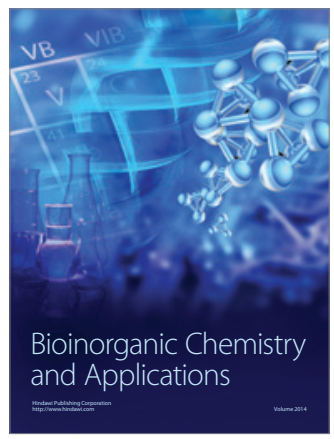

Inorganic Chemistry
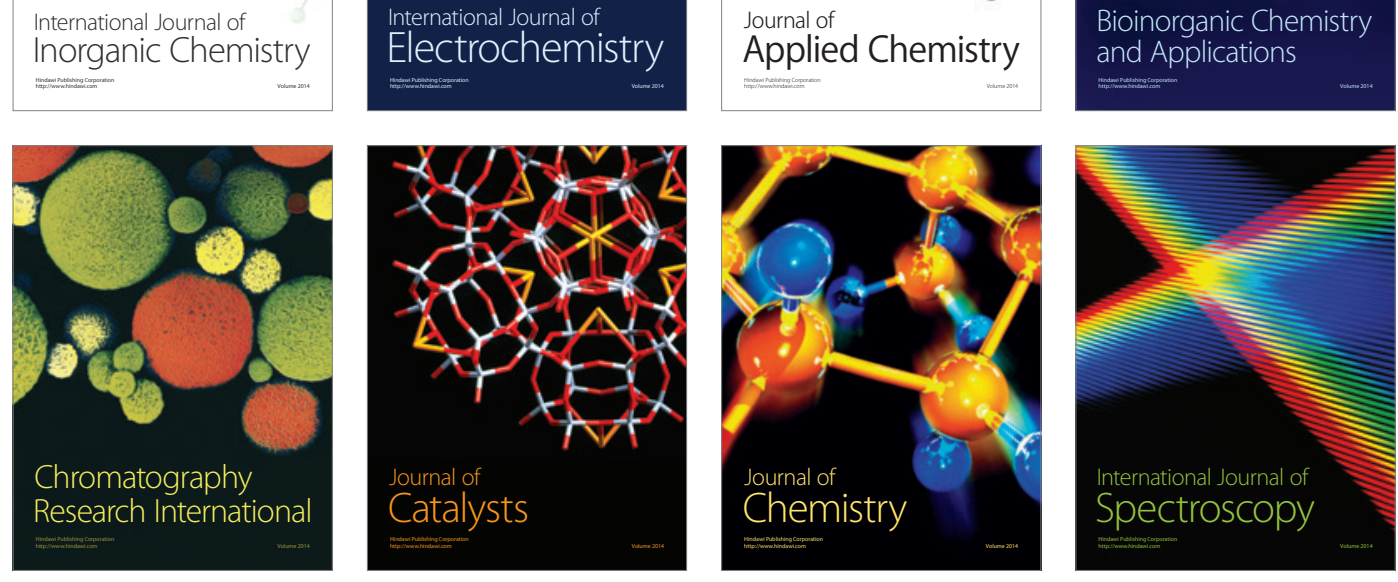